\title{
ASPP1/2 Regulate p53-Dependent Death of Retinal Ganglion Cells through PUMA and Fas/CD95 Activation In Vivo
}

\author{
Ariel M. Wilson, ${ }^{1}$ Barbara Morquette, ${ }^{1}$ Mohamed Abdouh,${ }^{2}$ Nicolás Unsain, ${ }^{3}$ Philip A. Barker, ${ }^{3}$ Elena Feinstein, ${ }^{4}$ \\ Gilbert Bernier, ${ }^{2}$ and Adriana Di Polo ${ }^{1,2}$ \\ ${ }^{1}$ Department of Pathology and Cell Biology and Groupe de Recherche sur le Système Nerveux Central, and 2Department of Ophthalmology, Maisonneuve- \\ Rosemont Hospital Research Center, University of Montreal, Montreal, Quebec H3T 1J4, Canada, ${ }^{3}$ Montreal Neurological Institute, McGill University, \\ Montreal, Quebec H3A 2B4, Canada, and ${ }^{4}$ Quark Pharmaceuticals, Research Division, Ness Ziona 70400, Israel
}

The transcription factor p53 mediates neuronal death in a variety of stress-related and neurodegenerative conditions. The proapoptotic activity of p53 is tightly regulated by the apoptosis-stimulating proteins of p53 (ASPP) family members: ASPP1 and ASPP2. However, whether ASPP1/2 play a role in the regulation of p53-dependent neuronal death in the CNS is currently unknown. To address this, we asked whether ASPP1/2 contribute to the death of retinal ganglion cells (RGCs) using in vivo models of acute optic nerve damage in mice and rats. Here, we show that p53 is activated in RGCs soon after injury and that axotomy-induced RGC death is attenuated in p53 heterozygote and null mice. We demonstrate that ASPP1/2 proteins are abundantly expressed by injured RGCs, and that short interfering (si)RNA-based ASPP1 or ASPP2 knockdown promotes robust RGC survival. Comparative gene expression analysis revealed that siASPPmediated downregulation of p53-upregulated-modulator-of-apoptosis (PUMA), Fas/CD95, and Noxa depends on p53 transcriptional activity. Furthermore, siRNA against PUMA or Fas/CD95 confers neuroprotection, demonstrating a functional role for these p53 targets in RGC death. Our study demonstrates a novel role for ASPP1 and ASPP2 in the death of RGCs and provides evidence that blockade of the ASPP-p53 pathway is beneficial for central neuron survival after axonal injury.

\section{Introduction}

The nuclear transcription factor p53 mediates the apoptosis of postmitotic neurons exposed to a wide range of insults (Culmsee and Mattson, 2005). Neuronal death induced by p53 has been documented in a variety of neurodegenerative diseases, suggesting a key role for this transcription factor in the regulation of neuronal viability after injury (Chatoo et al., 2011; Chang et al., 2012). Given its critical role in the control of cell death, several mechanisms exist to ensure tight regulation of p53 activity. The level of p53 protein is kept low in most cell types, including neurons (Soussi, 2000), via rapid and continuous degradation following ubiquitination by $\mathrm{Mdm} 2$ and $\mathrm{MdmX}$ (Wade et al., 2010). Additional control of $\mathrm{p} 53$ function is exerted via posttranslational modifications such as phosphorylation, acetylation,

Received June 1, 2012; revised 0ct. 30, 2012; accepted Dec. 10, 2012.

Author contributions: G.B. and A.D.P. designed research; A.M.W., B.M., M.A., N.U., P.A.B., E.F., and G.B. performed research; M.A. and E.F. contributed unpublished reagents/analytic tools; A.M.W. and A.D.P. analyzed data; A.M.W. and A.D.P. wrote the paper.

This work was supported by grants from the Canadian Institutes of Health Research (A.D.P.) and Quark Pharmaceuticals Inc. (A.D.P.) A.W. is a recipient of a studentship in excellence from the Faculty of Graduate Studies of the University of Montreal. A.D.P. is Chercheur Boursier National of Fonds de la recherche en santé du Québec. We thank Dr. T. E. Kennedy (Montreal Neurological Institute, McGill University) for helpful comments on the manuscript; Drs. H. Kalinski, H. Ashush, I. Mett (Quark Pharmaceuticals) for siRNA design and in vitro activity testing; and the Réseau de Recherche en Santé de la Vision.

Correspondence should be addressed to Adriana Di Polo, Department of Pathology and Cell Biology, University of Montréal, 2900 Boulevard Edouard-Montpetit, Pavillon Roger Gaudry, Room N-535, Montreal, Quebec H3T 1J4, Canada. E-mail: adriana.di.polo@umontreal.ca.

DOI:10.1523/JNEUROSCI.2635-12.2013

Copyright $\odot 2013$ the authors $\quad 0270-6474 / 13 / 332205-12 \$ 15.00 / 0$ and/or methylation, and by interactions with protein partners (Boehme and Blattner, 2009).

The identification of the apoptosis-stimulating proteins of p53 (ASPP), a family of ankyrin repeat and proline-rich domaincontaining proteins, has revealed a new form of p53 regulation. The ASPP family is composed of three members: ASPP1, ASPP2 and iASPP. ASPP2 was identified as a p53-binding protein in a yeast two-hybrid screen (Iwabuchi et al., 1994), and ASPP1 was found in a homology search (Nagase et al., 1998). ASPP1 and ASPP2 enhance p53-dependent death of tumor cells by selectively increasing the ability of p53 to activate proapoptotic gene transcription (Lopez et al., 2000; Ao et al., 2001; Samuels-Lev et al., 2001; Bergamaschi et al., 2006), whereas iASPP inhibits p53dependent cell death (Yang et al., 1999; Bergamaschi et al., 2003). ASPP1 and ASPP2 play a role in tumor suppression by increasing the ability of p53 to induce apoptosis, but not cell cycle arrest, in tumor-derived cell lines (Samuels-Lev et al., 2001; Slee et al., 2004). ASPP2-null mice die perinatally and although ASPP2 heterozygous mice survive to adulthood, they display a much higher propensity for developing tumors compared with wild-type counterparts (Vives et al., 2006). This may have physiological relevance since ASPP1/2 protein levels are reduced in many forms of cancer, a deficit associated with poor patient prognosis (Lossos et al., 2002; Liu et al., 2004, 2005; Agirre et al., 2006).

ASPP1/2 function has been examined solely in relation to tumor biology, but the role of these proteins in neuronal apoptosis has not been established. To address this, we asked whether ASPP1 or ASPP2 regulate death of adult retinal ganglion cells 
(RGCs) after axonal injury. RGCs are CNS neurons that undergo a predictable onset and time course of apoptotic death following optic nerve axotomy. Here, we demonstrate that ASPP1 and ASPP2 proteins are abundantly expressed by intact and injured RGCs, and that depletion of ASPP1 and ASPP2 using short interfering (si)RNAs promotes RGC survival in vivo. Moreover, our data support a critical role for the p53-upregulated-modulatorof-apoptosis (PUMA) and Fas/CD95 in siASPP2-mediated survival of injured RGCs. This study identifies a novel role for ASPP1 and ASPP2 as important regulators of neuronal death in the injured CNS.

\section{Materials and Methods}

Experimental animals. Animal procedures were performed in accordance with the guidelines of the Canadian Council on Animal Care for the use of experimental animals (www.ccac.ca). All surgeries were performed in adult, female Sprague Dawley rats $(180-200 \mathrm{~g})$ or in p53 knock-out mice under general anesthesia ( $2 \%$ Isoflurane, $0.8 \mathrm{~L} / \mathrm{min}$ ). p53 heterozygote

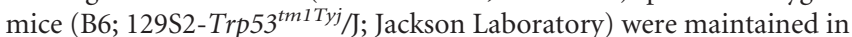
our animal facility and bred to produce p53-null and wild-type littermate control mice.

Axotomy-induced RGC death assay. Selective RGC death was induced by complete transection (axotomy) of the optic nerve leading to rapid onset and predictable apoptotic loss of these neurons (Berkelaar et al., 1994; Cheng et al., 2002). Before axotomy, RGCs were backlabeled by application of Fluorogold (2\%; Fluorochrome) to the superior colliculus, the primary target of these neurons in the rodent brain. To ensure that all RGCs were fully labeled before axonal injury, axotomy was performed $7 \mathrm{~d}$ after Fluorogold application. The left optic nerve was transected at $0.5-1 \mathrm{~mm}$ from the optic nerve head avoiding damage to the ophthalmic artery. Fundus examination was performed to check the integrity of the retinal circulation after surgery. The right eye was never operated on and served as intact control. At 1 or 2 weeks postlesion, rats were killed by transcardial perfusion with $4 \%$ paraformaldehyde (PFA), and the retinas were removed and flat-mounted vitreal side up on a glass slide for examination of the ganglion cell layer. Fluorogold-labeled neurons were counted within three square areas at distances of 1,2 , and $3 \mathrm{~mm}$ from the rat optic disc in each of the four retinal quadrants for a total of 12 retinal areas. In mice retinas, quantification was performed as in rats but sampled areas were localized at $0.25,0.625$, and $1 \mathrm{~mm}$ from the optic disc, for a total of 12 retinal areas. Microglia and macrophages, which may have incorporated Fluorogold after phagocytosis of dying RGCs, were excluded from our analysis of neuronal survival based on their morphology. Fluorescent staining was examined with a Zeiss Axioskop 2 Plus microscope (Carl Zeiss) and pictures were captured with a CCD video camera (Retiga, Qimaging) and analyzed with Northern Eclipse software (Empix Imaging).

Reverse transcription and quantitative real-time PCR. Total RNA was isolated from individual retinas using the RNEasy Mini kit (Qiagen) or TRIzol reagent (Invitrogen). cDNAs were generated from $0.5-3 \mu \mathrm{g}$ of total RNA using the Moloney Murine Leukemia Virus reverse transcriptase (Invitrogen). PCR for $\mathrm{p} 53$ was performed using the following primers: 553 forward: $5^{\prime}$-GAT GGTGACGGCCTGGCTCCT-3', p53 reverse: 5'-CTCGAAGCGCTC ACGCCCAC- $3^{\prime}, \beta$-actin forward: $5^{\prime}$-CACCACTTTCTACAATGAGC$3^{\prime}, \beta$-actin reverse: $5^{\prime}$-CGGTCAGGATCTTCATGAGG-3', and the following cycle conditions: $94^{\circ} \mathrm{C}$ for $1 \mathrm{~min}, 58^{\circ} \mathrm{C}$ for $1 \mathrm{~min}, 72^{\circ} \mathrm{C}$ for 1 $\mathrm{min}$. Reaction products were separated on agarose gels, visualized under UV light and digitalized using Gel Doc EZ System (Biorad). Densitometric analysis was performed with ImageJ software (NIH). For p53 target genes, quantitative real-time PCR (qPCR) was performed using the Platinum SYBRGreen SuperMix (Invitrogen) and a real-time PCR apparatus (BioRad). Rat primer sets were as follows: PUMA forward: 5' -CGGAGA CAAGAAGAGCAACA-3', PUMA reverse: 5'-TAGTTGGGCTCCATT TCTGG-3', Fas/CD95 forward: 5' -CCGACAACAACTGCTCAGAA-3', Fas/CD95 reverse: 5'-GGTGCAGTTCGTTTCCACTT-3', Bax forward: 5'-TGCAGAGGATGATTGCTGAC-3', Bax reverse: 5'-GATCAGCTC GGGCACTTTAG-3', Noxa forward: 5'-GGAGTGCACCGGACATAA CT-3', Noxa reverse: 5'-CTCCAATTCTCCGGAGTTGA-3', GAPDH forward: 5'-ATGGGAAGCTGGTCATCAAC-3', GAPDH reverse: 5'GTGGTTCACACCCATCACAA-3'. The ASPP2 primers (QT01599402) were purchased from Qiagen. Mouse primer sets were as follows: PUMA forward: 5'-CAAGAAGAGCAGCATCGACA-3, PUMA reverse: 5' -TAG TTGGGCTCCATTTCTGG3',Fas/CD95forward:5' -AAACAAACTGCA CCCTGACC-3', Fas/CD95 reverse: 5'-CAACCATAGGCGATTT CTGG-3', Bax forward: 5'-CACGTGACCGTGGTGCGCCG-3': Bax reverse: 5' -CCGCTCCCAAGCTGCTCCCCG-3', Noxa forward: 5' -CAC CGGACATAACTGTGGTT-3', Noxa reverse: 5' -TTGAGCACACTCG TCCTTCA-3' ${ }^{\prime}$, HRPT forward: 5' -ACTGTAATGATCAGTCAACGGG$3^{\prime}$, and HRPT reverse: $5^{\prime}$-GGCCTGTATCCAACACTTCG-3' $\beta$-actin, HRPT and GAPDH were used as internal standards for data calibration, and the $2^{-\Delta \Delta} \mathrm{Ct}$ formula was used for the calculation of differential gene expression, as described previously (Chatoo et al., 2009).

siRNA. The siRNA molecules against ASPP1, ASPP2, and Cy3-labeled siRNA were designed at Quark Pharmaceuticals. The control siRNA against GFP has been described previously (Hamar et al., 2004). All these siRNAs were stabilized by alternating 2' $\mathrm{O}$-methylation (Czauderna et al., 2003) and were synthesized by BioSpring. The following siRNA sequences (sense strands) for ASPP1 and ASPP2 were tested with similar results, ASPP1: 5' -GGAGAGAAGCACACTGAAA-3' ' 5' -CAGCGTTTA CATTTCCTAA- ${ }^{\prime}$, and 5' -CCGTGTTCTTGAGCAACAA-3'; ASPP2: 5' -AGGGAGTGTTTGAATAAGC-3' and 5' -CACCCAGAGAACATTTA TT-3'. The siRNA sequences (sense strands) against PUMA: 5' -GAGCGG CGGAGACAAGAAGAGUU-3'; Fas/CD95:5' -GUGCAAGUGCAAACC AGACUU-3'; and Noxa: 5' -CAAGGAAAGCUGACGGAGA-3', 5' -GAA CAGAAGUGGCUACGAA-3', 5' -CCAUGGAUUUCCUCGGCAA-3', and $5^{\prime}$-AAGCAAUGGUCGUCGAGCA-3' were purchased from Thermo Fisher Scientific. The fluorescent siRNA used for the visualization of intraocular distribution, sequence 5'-GUGCCAACCUGAUGCAGCU-3' (sense strand), contained a Cy3 fluorophore at the $3^{\prime}$ end of the antisense strand.

Intravitreal injections. siRNA against ASPP1, ASPP2, PUMA, Fas/ CD95, Noxa, siCy3, or control siGFP $(2 \mu \mathrm{g} / \mu \mathrm{l}$, total volume: $5 \mu \mathrm{l})$ were injected into the vitreous chamber of the left eye using a Hamilton syringe fitted with a 32-gauge glass microneedle. PBS was used as vehicle control. The sclera was exposed and the tip of the needle was inserted at a $45^{\circ}$ angle through the sclera and retina into the vitreous space using a posterior approach. This route of administration avoided injury to the iris or lens, which can promote RGC survival (Mansour-Robaey et al., 1994; Leon et al., 2000).

Retinal immunohistochemistry. Animals were perfused transcardially with $4 \%$ PFA and retinal cryosections $(16 \mu \mathrm{m})$ were prepared as previously described (Pernet et al., 2005; Lebrun-Julien et al., 2009). Primary antibodies were added to the retinal sections in blocking solution and incubated overnight at $4^{\circ} \mathrm{C}$ : phospho-p53 (Ser15; $20 \mu \mathrm{g} / \mathrm{ml}$; Abcam), ASPP1 ( $1 \mu \mathrm{g} / \mathrm{ml}$; Bethyl Laboratories), ASPP2 $(0.5 \mu \mathrm{g} / \mathrm{ml}$; Bethyl Laboratories), or iASPP $(0.5 \mu \mathrm{g} / \mathrm{ml}$; Bethyl Laboratories). For phospho-p53 (Ser15), retinas were subjected to heat-mediated antigen retrieval by incubating sections in $0.01 \mathrm{~m}$ sodium citrate in $0.5 \%$ Tween $20(\mathrm{pH} 6)$ at $85-90^{\circ} \mathrm{C}$ for $30 \mathrm{~min}$. Blocking peptides $(2.5 \mu \mathrm{g} / \mathrm{ml}$; Bethyl Laboratories) were incubated overnight with ASPP1 or ASPP2 primary antibodies (5:1 ratio) before application onto retinal sections. Sections were washed and incubated with secondary antibodies: anti-rabbit IgG (1-8 $\mu \mathrm{g} / \mathrm{ml}$; Cy3, Alexa 594, or Alexa 488; Jackson ImmunoResearch Laboratories). Fluorescent labeling was observed with a microscope Zeiss AxioSkop 2 Plus (Carl Zeiss).

Western blot analysis. Whole fresh retinas were rapidly dissected and homogenized with an electric pestle (Kontes) in ice-cold lysis buffer (20 $\mathrm{mm}$ Tris $\mathrm{pH}$ 8.0, $135 \mathrm{~mm} \mathrm{NaCl}, 1 \% \mathrm{NP}-40,0.1 \%$ SDS, and 10\% glycerol supplemented with protease inhibitors). Protein homogenates were centrifuged at 10,000 rpm for $10 \mathrm{~min}$, and the supernatants were removed and resedimented to yield solubilized extracts. Retinal extracts were resolved on SDS polyacrylamide gels and transferred to nitrocellulose membranes (Bio-Rad Life Science). Blots were incubated overnight at $4^{\circ} \mathrm{C}$ with each of the following primary antibodies: phospho-p53 (Ser15; $2 \mu \mathrm{g} / \mathrm{ml}$; Abcam), ASPP1 (1 $\mu \mathrm{g} / \mathrm{ml}$; Bethyl Laboratories), ASPP2 (0.5 $\mu \mathrm{g} / \mathrm{ml}$; Bethyl Laboratories), iASPP $(0.5 \mu \mathrm{g} / \mathrm{ml}$; Bethyl Laboratories), 
A

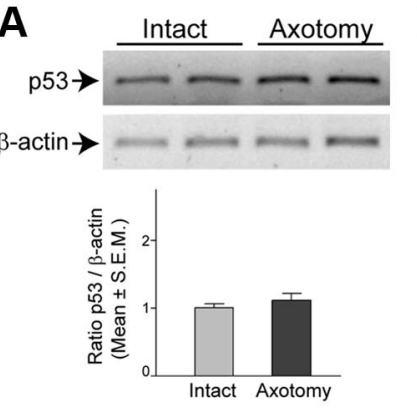

B
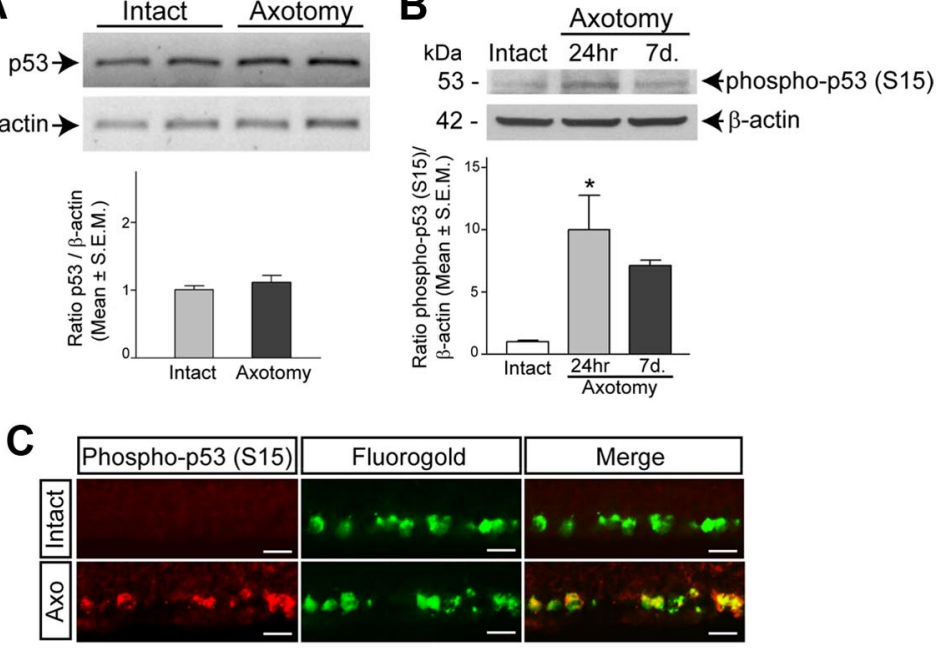

D
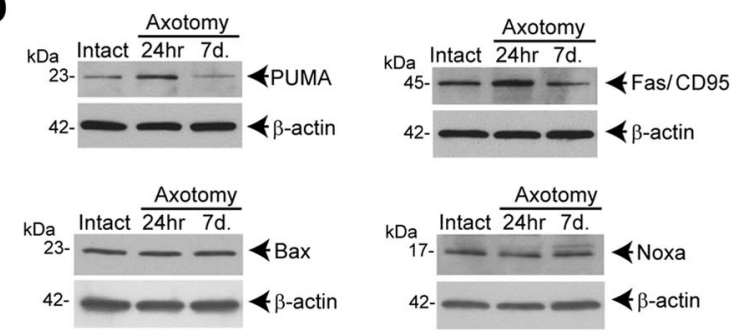

E

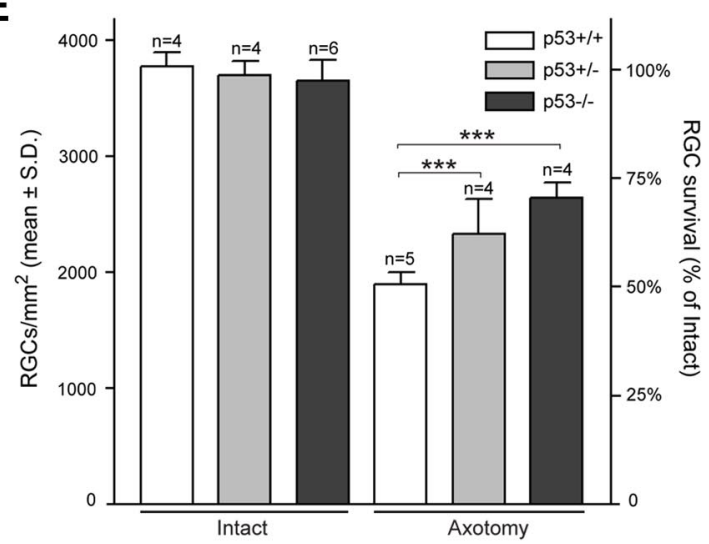

Figure 1. Axotomized RGCs die in a p53-dependent manner. $\boldsymbol{A}, \mathrm{RT}-\mathrm{PCR}$ analysis revealed that p53 mRNA levels do not change at 1 or $3 \mathrm{~d}$ (shown here) after axotomy with respect to noninjured retinas (Student's $t$ test, $p>0.05$ ). $\boldsymbol{B}$, In contrast, a significant increase in axotomy-induced phosphorylation of $\mathrm{p} 53$ at serine $15(S 15)$ was readily detected at $1 \mathrm{~d}$ after axotomy, but returned to basal levels at $7 \mathrm{~d}$ postlesion (ANOVA, ${ }^{*} p<0.05$ ). C, Retinal immunostaining of Fluorogold-labeled RGCs confirmed that p53 phosphorylation (activation) was detected in these neurons at $1 \mathrm{~d}$ after axotomy. Scale bars, $10 \mu \mathrm{m}$. D, Protein levels of the p53 apoptotic targets PUMA and Fas/CD95 increased at $1 \mathrm{~d}$ after axotomy, but returned to normal levels at $7 \mathrm{~d}$ postinjury. Bax and Noxa remained unchanged. $\boldsymbol{E}$, Analysis of RGC loss quantified at 1 week after axotomy in p53-null, heterozygote, and wild-type retinas demonstrated an allelic dose dependency on p53 (ANOVA, $\left.{ }^{* * *} p<0.001\right)$. Data are expressed as RGC densities $\left(\mathrm{RGCs} / \mathrm{mm}^{2}\right.$; mean $\pm S D)$.

Bax $(1.5 \mu \mathrm{g} / \mathrm{ml}$; N20; Santa Cruz Biotechnology), PUMA ( $1 \mu \mathrm{g} / \mathrm{ml}$; Abcam), Noxa $(0.5 \mu \mathrm{g} / \mathrm{ml}$; Sigma-Aldrich), Fas/CD95 (1 $\mu \mathrm{g} / \mathrm{ml}$; BD Transduction Laboratories), or $\beta$-actin $(0.5 \mu \mathrm{g} / \mathrm{ml}$; Sigma-Aldrich $)$. Membranes were incubated in anti-rabbit or anti-mouse peroxidaselinked secondary antibodies $(0.5 \mu \mathrm{g} / \mathrm{ml}$; GE Healthcare $)$. Blots were developed with a chemiluminescence reagent (ECL; GE Healthcare) and exposed to X-OMAT imaging film (Eastman Kodak). Densitometric analysis was performed using Scion Image software on scanned autoradiographic films obtained from a series of three independent Western blots, each performed using retinal samples from distinct experimental groups.
Statistical analyses. Data analysis and statistics were performed using the GraphPad Instat software by a one-way ANOVA followed by the Bonferroni post hoc test, or by a Student's $t$ test.

\section{Results}

Axotomized RGCs die in a

p53-dependent manner

p53 protein is abundantly expressed in the developing retina, but it is substantially downregulated during maturation (O'Connor et al., 2008). To establish whether p53 gene expression or activity increase following optic nerve injury, we performed biochemical and immunohistochemical analysis of retinal samples after axotomy. While p53 mRNA levels did not change at 1 (data not shown) or $3 \mathrm{~d}$ (Fig. 1A) after injury, a significant increase in injury-induced phosphorylation of p53 at serine 15 (S15), a key phosphorylation target during p53 activation (Dumaz and Meek, 1999; Unger et al., 1999), was readily detected at 1 d postlesion (Fig. 1B). Immunostaining of Fluorogold-labeled retinas demonstrated selective phospho-p53 upregulation in RGCs at $1 \mathrm{~d}$ after axotomy (Fig. 1C), a time point that precedes the onset of RGC death in this model (Villegas-Pérez et al., 1993; Berkelaar et al., 1994). Phosphorylation of p53 at S15 has been shown to be sufficient to induce apoptosis of human glioma cells and leads to selective increase of the proapoptotic p53 targets Fas/CD95 and PUMA (Amano et al., 2009). Consistent with axotomy-induced phosphorylation of retinal p53 at S15, we observed increased protein expression of PUMA and Fas/CD95 at $1 \mathrm{~d}$ after axotomy, whereas levels of Bax and Noxa did not change (Fig. 1D). Of interest, phosphop53 (S15), PUMA, and Fas/CD95 proteins dropped to basal levels at $7 \mathrm{~d}$ postinjury (Fig. $1 B, D$ ), indicating that axotomy leads to early and transient activation of this pathway.

To address the functional role of increased p53 activity in axotomy-induced RGC death, we analyzed the density of RGCs in p53 heterozygote $\left(p 53^{+/-}\right)$and null $\left(p 53^{-/-}\right)$mice subjected to optic nerve injury. RGCs were first labeled by application of the retrograde tracer Fluorogold to the superior colliculus, followed by axotomy and quantification of neuronal survival. Figure $1 E$ shows that $73 \%$ of RGCs survived in $p 53^{-1-}$ retinas and $65 \%$ in $p 53^{+/-}$retinas, while only $50 \%$ remained in wild-type retinas at 1 week postlesion. The total density of RGCs in noninjured (intact) $p 53^{+/+}, p 53^{+/-}$, and $p 53^{-/-}$adult retinas was similar, indicating that $\mathrm{p} 53$ is not required for developmental programmed RGC death, consistent with previous findings ( $\mathrm{Li}$ et al., 2002). These data demonstrate that optic nerve axotomy leads to activation of p53 in RGCs and 
that p53 plays a role in axotomy-induced RGC death in a dosedependent manner.

\section{ASPP1 and ASPP2 are expressed by adult RGCs}

To characterize the role of ASPP1 and ASPP2 in RGC death, we first determined which retinal cells express them. Retinal immunohistochemistry showed abundant expression of endogenous ASPP1 and ASPP2 in the ganglion cell layer (GCL) (Fig. 2A,K) while other retinal layers were virtually devoid of ASPP1/2. Since displaced amacrine cells account for $\sim 40 \%$ of the total number of neurons in the GCL (Perry, 1981), we performed colocalization studies where RGCs were retrogradely labeled with Fluorogold (Fig. 2B,L). All Fluorogold-labeled neurons displayed robust ASPP1 and ASPP2 immunoreactivity (Fig. $2 C-F, M-P$ ), indicating that adult RGCs are endowed with high levels of ASPP1/2 proteins. Colabeling with the nuclear marker DAPI demonstrated that ASPP1 had a nuclear and cytoplasmic (perinuclear) localization within RGCs (Fig. $2 \mathrm{H}-J$ ), while ASPP2 was primarily found in RGC nuclei (Fig. 2R-T). ASPP1 and ASPP2 blocking peptides resulted in absence of staining (Fig. $2 G, Q$ ), confirming the specificity of the ASPP1 and ASPP2 antibodies.

Following axotomy, there were no detectable changes in the levels or subcellular localization of ASPP1, ASPP2, or the antiapoptotic member iASPP visualized by retinal immunohistochemistry (Fig. 3A). Analysis of protein homogenates at 24 or $48 \mathrm{~h}$ (Figs. 3,4 ) after axotomy confirmed that ASPP1, ASPP2, and iASPP levels were similar to those in intact, noninjured retinas (Fig. $3 B, C$ ). A time course analysis of ASPP proteins up to $5 \mathrm{~d}$ postaxotomy revealed no change in their levels with respect to control retinas (data not shown). Collectively, these data indicate that ASPP1 and ASPP2 are abundantly expressed by intact and axotomized RGCs.

\section{Selective knockdown of retinal ASPP1 or ASPP2 by intravitreal siRNA delivery}

To investigate the role of ASPP1/2 proteins in retinal neuron death, we synthesized siRNA sequences against ASPP1 or ASPP2. We first examined whether intraocular siRNA delivery led to effective uptake by adult RGCs using a Cy3-tagged control siRNA. Figure 4 shows that a single intravitreal injection of Cy3siRNA resulted in robust Cy3 labeling in RGCs as early as $5 \mathrm{~h}$ after administration (Fig. 4A-F). The colocalization of $\mathrm{Cy} 3$ and Fluorogold confirmed that siRNA was rapidly taken up by RGCs after intravitreal delivery (Fig. 4G-I).

To assess the ability of siRNAs to knockdown retinal ASPP1 or ASPP2 protein expression in vivo, we performed Western blot analysis of retinal homogenates from eyes that received a single injection of each siRNA at the time of axotomy. Administration of siRNA against ASPP1 (siASPP1) led to a significant reduction of retinal ASPP1 protein at $24 \mathrm{~h}$ after delivery, while a control siRNA against GFP (siGFP) had no effect (Fig. $4 J, K$ ). Importantly, siASPP1 did not reduce the protein levels of the other family members, ASPP2 or iASPP, confirming the specificity of the siRNA. Similarly, siRNA against ASPP2 (siASPP2) selectively depleted retinal ASPP2 protein levels without reducing ASPP1 or iASPP levels (Fig. $4 L, M$ ). Quantification of ASPP1 or ASPP2 protein levels at $24 \mathrm{~h}$ after treatment with siASPP2 or siASPP1, respectively, did not show a compensatory increase in these proteins (Fig. $4 K, M$, hatched bars). Endogenous levels of ASPP1 and ASPP2 proteins returned to basal at $48 \mathrm{~h}$ after siRNA delivery (Fig. $4 J-M$, black bars). Immunohistochemistry of axotomized retinas treated with siASPP1 or siASPP2 confirmed that siRNA- mediated knockdown of ASPP1/2 occurred in RGCs, visualized with Fluorogold (Fig. 4N,O). These data demonstrate that intravitreal delivery of siRNA results in rapid and effective uptake by RGCs, and that siRNAs against ASPP1 and ASPP2 promote transient depletion of ASPP proteins in these neurons.

\section{ASPP1 and ASPP2 knockdown protects RGCs from axotomy-induced death}

To determine whether ASPP1 and ASPP2 were required for axotomy-induced RGC death, we asked whether targeted siRNAmediated knockdown promoted RGC survival. For this purpose, RGCs were retrogradely labeled before optic nerve transection and intravitreal injections of siRNA against ASPP1 or ASPP2 were performed concomitant with axotomy. Flat-mounted retinas from eyes treated with siASPP1 or siASPP2 consistently displayed higher densities of Fluorogold-labeled RGCs than those treated with control siGFP (Fig. 5A-D). Quantitative analysis demonstrated that ASPP1 or ASPP2 knockdown resulted in substantial RGC survival relative to vehicle-treated (PBS) or control siGFP-treated eyes (Fig. 5E), with siASPP2 promoting slightly more neuroprotection $\left(79 \% ; 1636 \pm 62 \mathrm{RGCs} / \mathrm{mm}^{2}\right)$ than siASPP1 $\left(69 \% ; 1430 \pm 34 \mathrm{RGCs} / \mathrm{mm}^{2}\right)$ at 1 week postinjury. All the siRNA sequences against ASPP1 or ASPP2 yielded similar results.

We also examined the effect of siASPP1 and siASPP2 on RGC survival at 2 weeks after axotomy, a time-point when few RGCs remain alive in the absence of treatment (Lebrun-Julien et al., 2009 ). Figure $5 E$ shows that only $6 \%$ of RGCs survived in animals treated with vehicle or control siGFP $\left(130 \pm 7 \mathrm{RGCs} / \mathrm{mm}^{2}\right)$, whereas $26 \%$ RGC survival was observed in animals that received siASPP1 or siASPP2 $\left(542 \pm 30 \mathrm{RGCs} / \mathrm{mm}^{2}\right.$ or $509 \pm 24 \mathrm{RGCs} /$ $\mathrm{mm}^{2}$, respectively). The combination of siASPP1 and siASPP2 did not increase RGC survival further (Fig. 5E, black bars), suggesting that ASPP1 and ASPP2 activate redundant pathways to promote RGC death. We conclude that ASPP1 and ASPP2 are required for p53-dependent axotomy-induced death of RGCs in the adult retina.

\section{siASPP2 protects axotomized RGCs through downregulation} of the $\mathrm{p} 53$ proapoptotic targets PUMA and Fas/CD95

To investigate the mechanisms by which ASPP protein knockdown might lead to RGC neuroprotection after optic nerve injury, we examined changes in $\mathrm{p} 53$ proapoptotic targets at the mRNA and protein levels (Figs. 6, 7). We focused on siASPP2 because it confers enhanced neuroprotection over siASPP1. Realtime qPCR analysis of rat retinal samples at $6 \mathrm{~h}$ after axotomy and siASPP2 administration, a time-point when siRNA is already present in RGCs (Fig. 4A-I), revealed downregulation of ASPP2 and the p53 apoptotic targets PUMA, Fas/CD95, and Noxa compared with uninjured or control siRNA-treated retinas (Fig. 6A). There was no change in Bax expression levels. To further substantiate our findings, we performed qPCR in retinal samples from p53-null mice and wild-type littermate controls collected at $6 \mathrm{~h}$ after axotomy with or without siASPP2 treatment. Overall, the transcript levels of PUMA, Fas/CD95, and Noxa were significantly reduced in noninjured or axotomized p53-null mice with respect to wild-type littermates, suggesting that these genes are transcriptionally regulated by p53 (Fig. 6B,C,E). More importantly, ASPP2 knockdown effectively reduced PUMA, Fas/CD95, and Noxa gene expression in axotomized retinas from p53 wildtype mice but not from p53 knock-out mice (Fig. $6 B, C, E$ ), while Bax remained unchanged (Fig. 6D). siASPP2 did not reduce PUMA and CD95 expression further relative to the already 

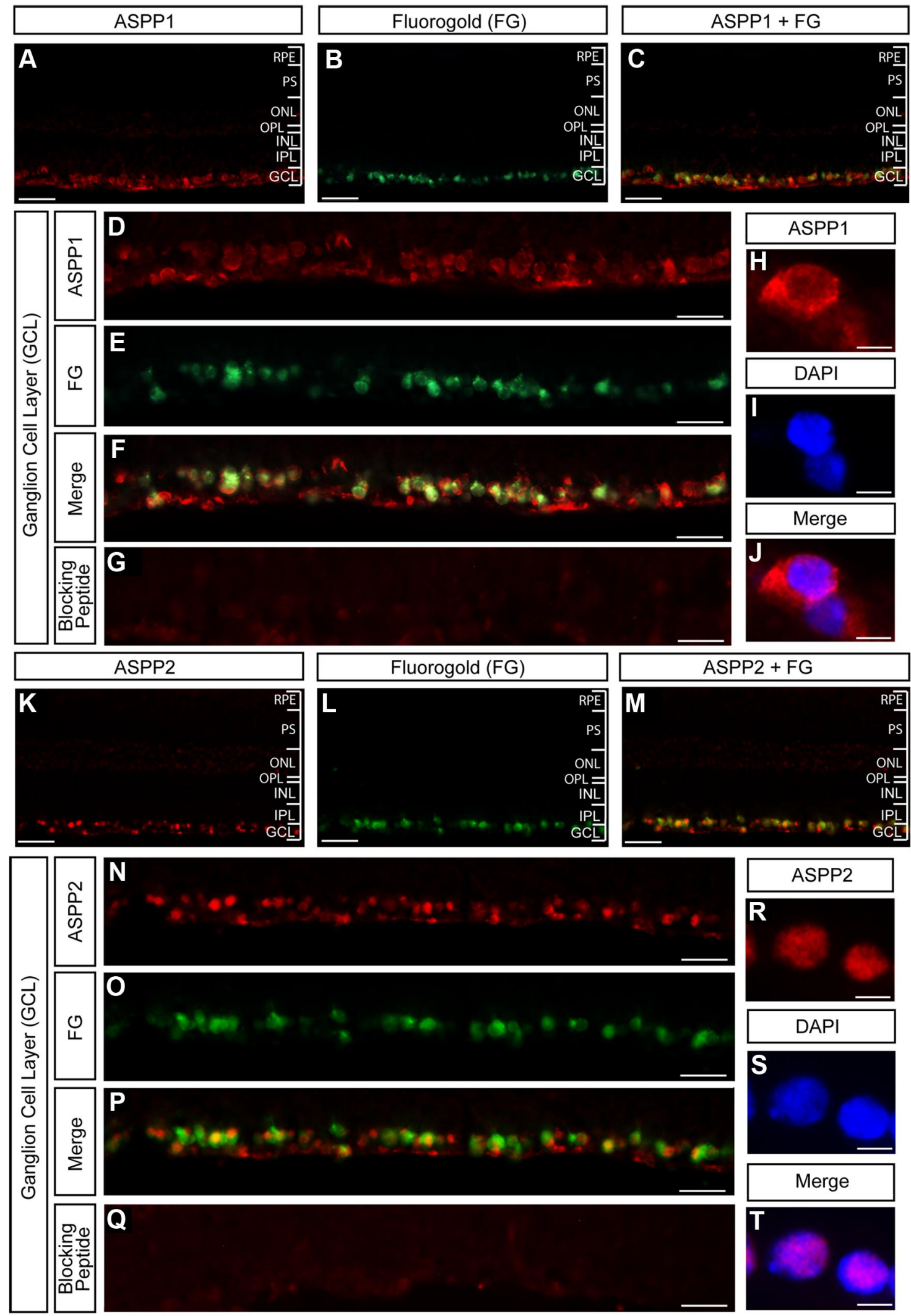

Figure 2. ASPP1 and ASPP2 are expressed by adult RGCs. Retinal immunofluorescence demonstrated abundant expression of endogenous ASPP1 (A-G) and ASPP2 (K-Q) in RGCS visualized with the retrograde tracer Fluorogold. DAPI staining showed that ASPP1 is present in RGC nuclei and cytoplasm (perinuclear) $(\boldsymbol{H}-\boldsymbol{J})$, while ASPP2 is primarily in the nuclei (R-T). ASPP1 and ASPP2 blocking peptides resulted in absence of staining $(\mathbf{G}, \mathbf{Q})$, confirming the specificity of the ASPP1 and ASPP2 antibodies. Scale bars: $\boldsymbol{A}-\mathbf{C}$ and $\boldsymbol{K}-\boldsymbol{M}, 70 \mu \mathrm{m} ; \mathbf{D}-\mathbf{G}$ and $\boldsymbol{N}-\mathbf{Q}, 50 \mu \mathrm{m} ; \boldsymbol{H}-\boldsymbol{J}$ and $\boldsymbol{R}-\boldsymbol{T}, 10$ $\mu \mathrm{m}$. RPE, Retinal pigment epithelium; PS, photoreceptor segments; $0 \mathrm{NL}$, outer nuclear layer; $\mathrm{OPL}$, outer plexiform layer; INL, inner nuclear layer; IPL, inner plexiform layer; $\mathrm{GCL}$, ganglion cell layer; FG, Fluorogold. 
reduced levels found in p53-null mice. Collectively, these data demonstrate that siASPP2-mediated knockdown of PUMA, Fas/CD95, and Noxa depends on p53 transcriptional activity.

Western blot analysis of axotomized retinal samples at $24 \mathrm{~h}$ after siRNA administration showed that siASPP2 reduced PUMA and Fas/CD95 protein levels relative to control siGFP (Fig. $7 A, B$ ), while Bax and Noxa levels did not change with any of the treatments (Fig. 7C,D). These findings, supported by our observation that PUMA and Fas/CD95 are upregulated following axotomy (Fig. 1D), raised the possibility that they might play a role in the p53-dependent death of axotomized RGCs. To test this, we administered siRNAs against PUMA or Fas/CD95 at the time of axotomy and quantified retrogradely labeled RGCs at 1 week postinjury. siPUMA or siFas/CD95 effectively downregulated endogenous retinal PUMA or Fas/CD95, respectively (Fig. 7E,F). Importantly, a substantial increase in RGC survival was observed in retinas exposed to $\operatorname{siPUMA}\left(77 \% ; 1597 \pm 38 \mathrm{RGCs} / \mathrm{mm}^{2}\right.$, $n=4)$ or siFas/CD95 (69\%; $1432 \pm 71$ $\left.\mathrm{RGCs} / \mathrm{mm}^{2}, n=4\right)$ relative to siGFPtreated controls (Fig. 7H). Unlike PUMA or Fas/CD95, siASPP2-mediated decrease in Noxa transcript levels at $6 \mathrm{~h}$ after axotomy (Fig. 6) did not correlate with Noxa protein reduction at $24 \mathrm{~h}$ postinjury (Fig. $7 D$ ). Since this discrepancy might simply reflect a difference in the kinetics of Noxa mRNA and protein synthesis (Aikawa et al., 2010; Armstrong et al., 2010), we also used a siRNA against Noxa to assess its role on RGC survival at 1 week after axotomy. siNoxa effectively reduced endogenous Noxa protein levels (Fig. $7 G$ ), but did not result in significant RGC protection (Fig. $7 H$ ), suggesting that although Noxa is transcriptionally regulated by p53, it does not play a prominent role in RGC death. We conclude that ASPP2 knockdown protects RGCs via downregulation of the p53 targets PUMA and Fas/ CD95, and that these molecules mediate axotomy-induced RGC apoptosis.

\section{Discussion}

The present study explored the functional role of the p53 coactivators ASPP1 and ASPP2 in the regulation of injury-induced death of adult retinal neurons in vivo. Our data support four major conclusions. First, axotomy-induced RGC death is mediated inter alia through p53 activation in a gene dose-dependent manner. Second, ASPP1 and ASPP2 proteins are abundantly expressed by intact and injured
A

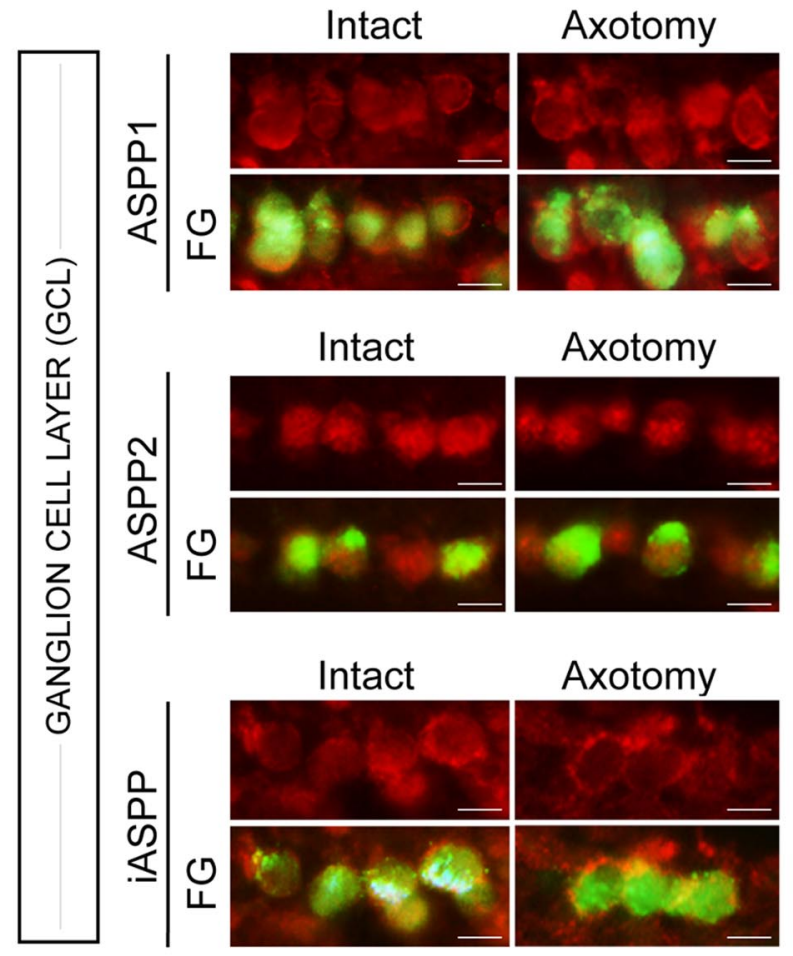

B

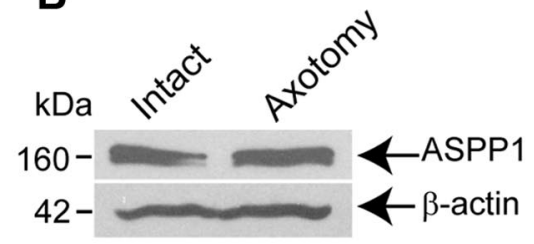

C
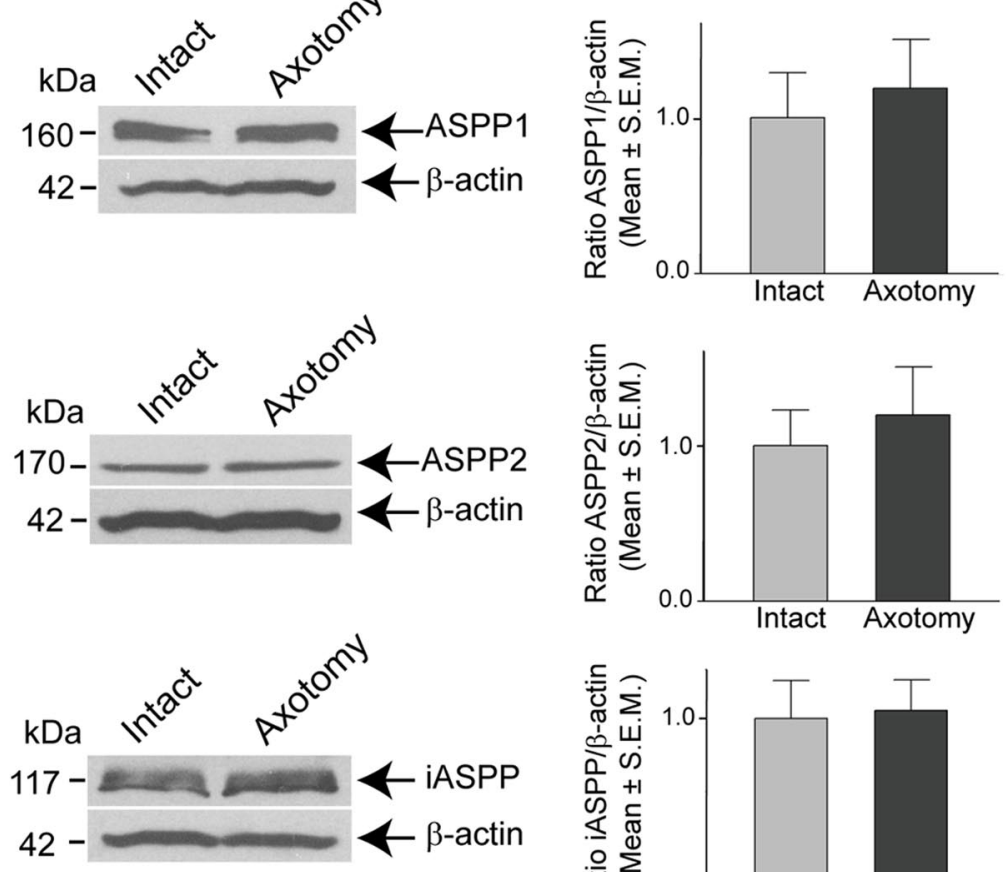

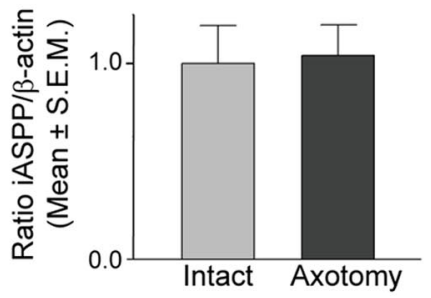

Figure 3. Expression of ASPP family members after optic nerve axotomy. $\boldsymbol{A}$, The levels or subcellular localization of ASPP1, ASPP2, or the anti-apoptotic member iASPP, visualized by retinal immunohistochemistry and Fluorogold (FG) staining, did not change at $48 \mathrm{~h}$ after optic nerve injury. Scale bars, $10 \mu \mathrm{m}$. B, Analysis of protein homogenates confirmed that ASPP1, ASPP2, and iASPP levels in axotomized retinas collected at $48 \mathrm{~h}$ were similar to those in intact, noninjured retinas. The bottom blot is the same as the top, but probed with an antibody that recognizes $\beta$-actin used to confirm equal protein loading. $\boldsymbol{C}$, Densitometric analysis of Western blots, showing the ratio of ASPP proteins relative to $\beta$-actin, confirmed that there is no significant change in protein expression after injury (Student's $t$ test, $p>0.05$ ). 

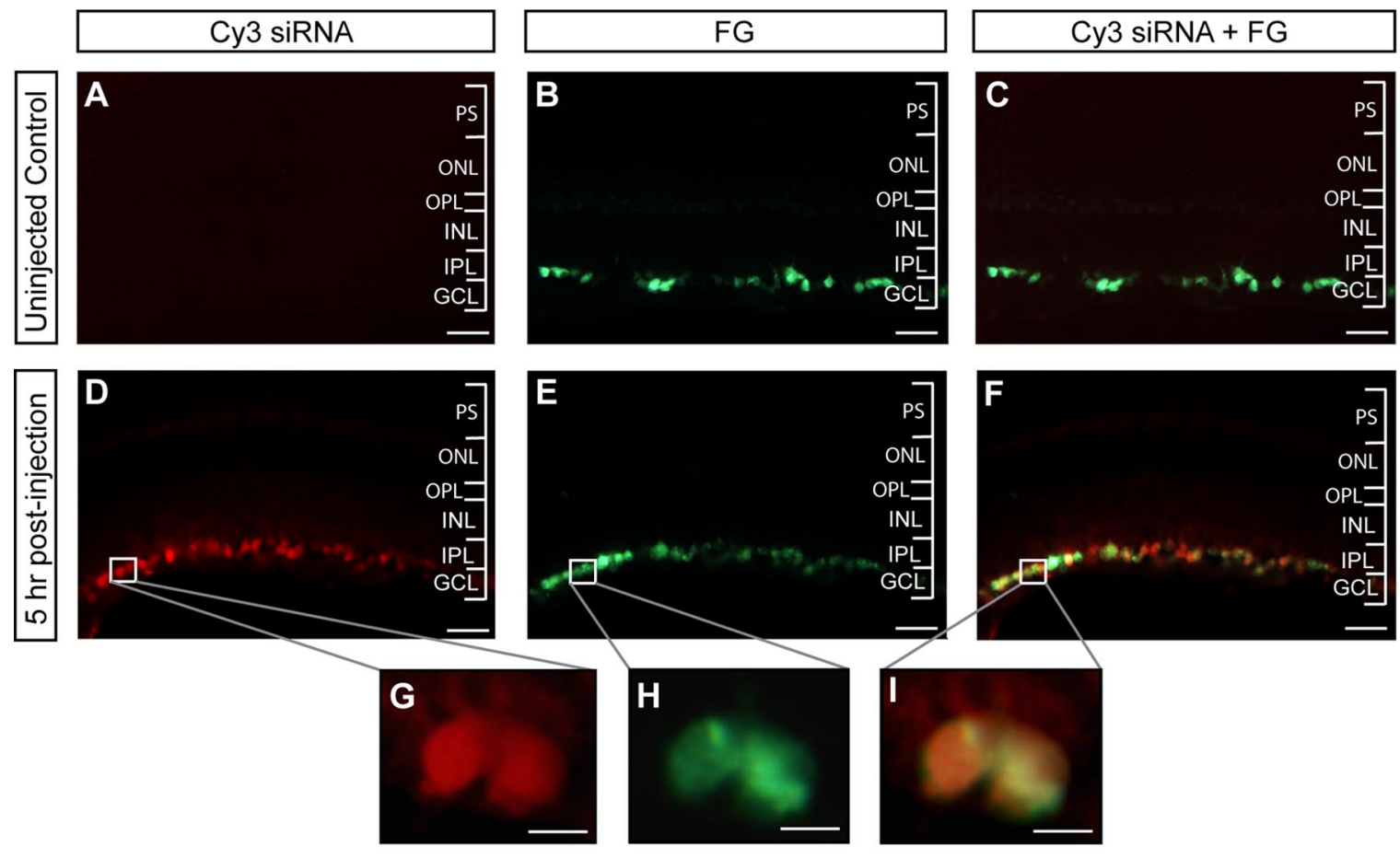

J

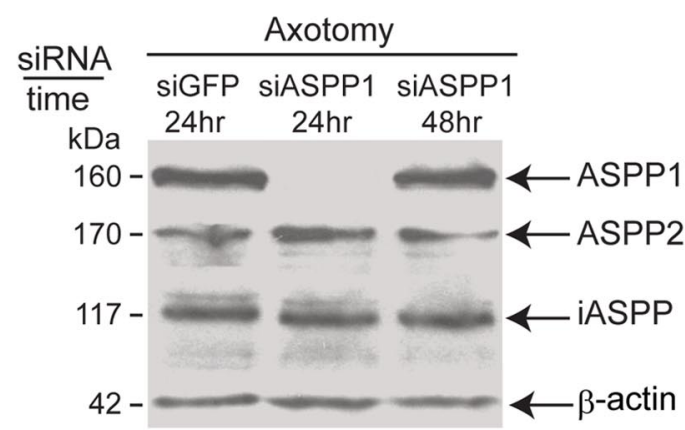

L

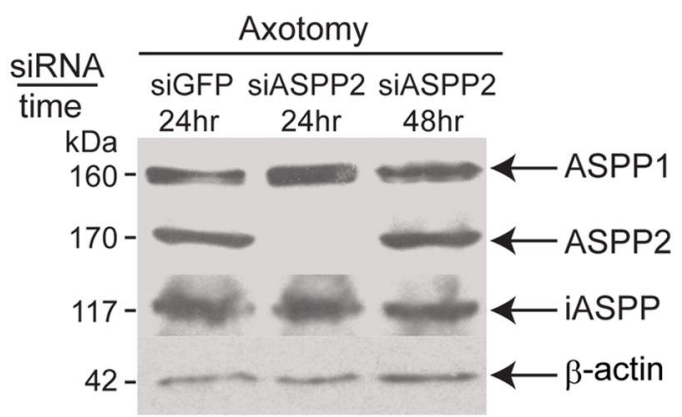

$\mathrm{K}$

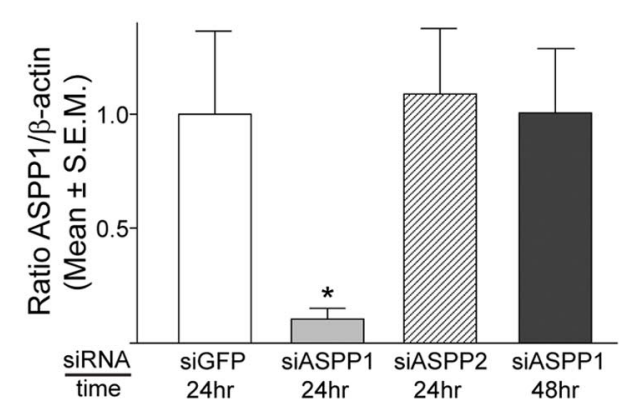

$\mathrm{M}$
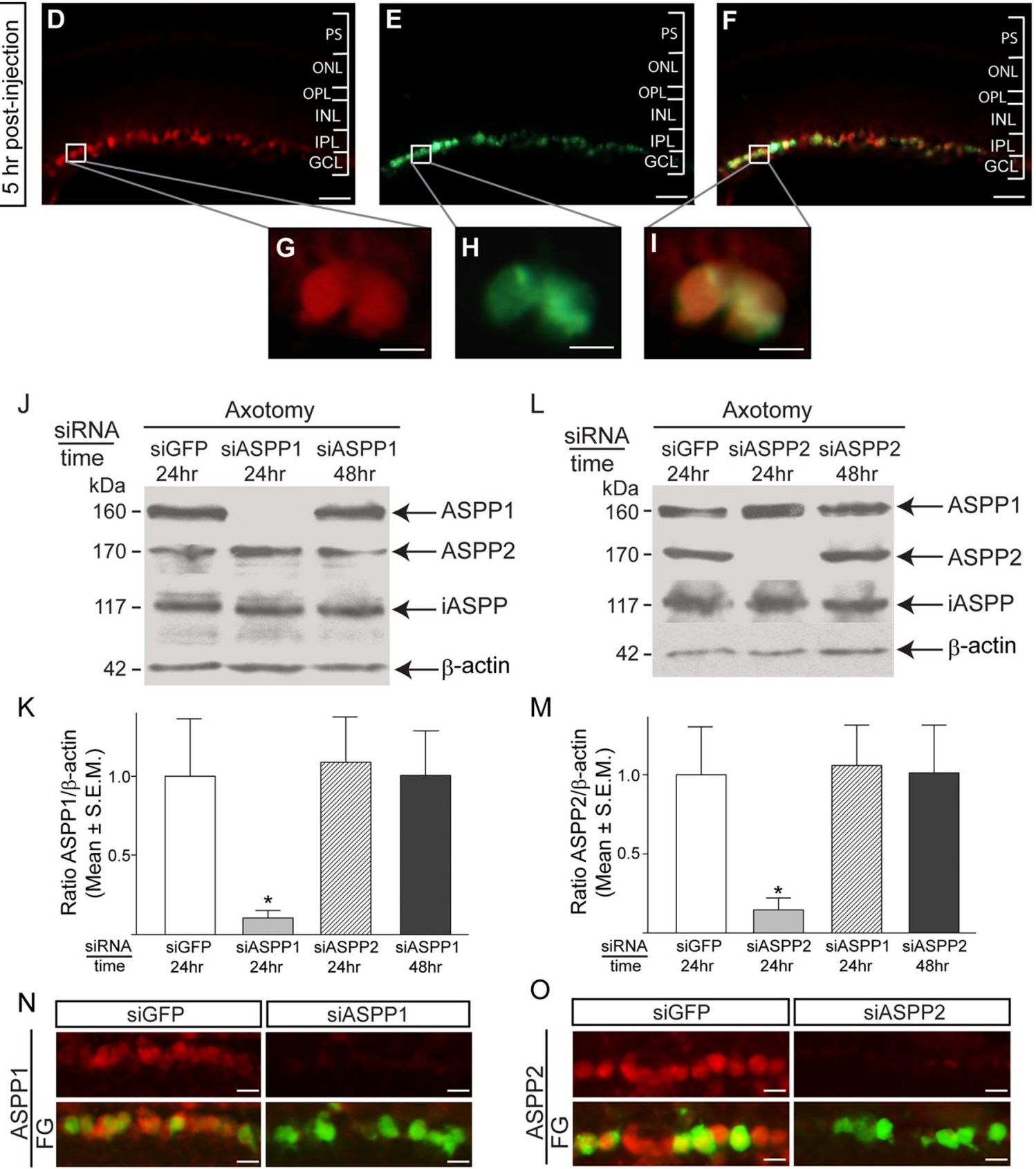

Figure 4. Selective knockdown of retinal ASPP1 or ASPP2 by intravitreal siRNA delivery. Intravitreal delivery of Cy3-tagged siRNA resulted in rapid and effective uptake by RGCs. Lack of Cy3 fluorescence in noninjected control retinas $(\boldsymbol{A}-\boldsymbol{C})$ contrasted with robust $C y 3$ labeling in $\mathrm{RGCS}$, visualized with Fluorogold $(\mathrm{FG})(\boldsymbol{D}-\boldsymbol{I})$, as early as $5 \mathrm{~h}$ after siRNA administration. $J-M$, Intravitreal delivery of siRNA against ASPP1 (siASPP1) led to a significant reduction of retinal ASPP1 protein at $24 \mathrm{~h}$ after delivery while control siRNA against GFP (siGFP) had no effect (ANOVA, ${ }^{*} p<0.05$ ). siASPP1 did not decrease or increase the protein levels of the other family members, ASPP2 or iASPP, confirming the specificity of the siRNA. Similarly, siRNA against ASPP2 (siASPP2) selectively depleted retinal ASPP2 protein levels (ANOVA, ${ }^{*} p<0.05$ ) without altering ASPP1 or iASPP levels. Endogenous levels of both ASPP1 and ASPP2 proteins returned to basal at $48 \mathrm{~h}$ after siRNA delivery. $\mathbf{N}, \mathbf{0}$, Immunohistochemistry of axotomized retinas at $24 \mathrm{~h}$ after siASPP1 or siASPP2 administration confirmed that siRNA-mediated knockdown of ASPP1/2 occurred in RGCS, visualized with Fluorogold. Scale bars: $\mathbf{A}-\boldsymbol{F}, 50 \mu \mathrm{m} ; \mathbf{G}-\mathbf{I}, 10 \mu \mathrm{m} ; \mathbf{N}-\mathbf{0}, 12 \mu \mathrm{m}$. PS, Photoreceptor segments; $\mathbf{O N L}$, outer nuclear layer; $\mathrm{OPL}$, outer plexiform layer; INL, inner nuclear layer; IPL, inner plexiform layer; $\mathrm{GCL}$, ganglion cell layer. 
RGCs. Third, selective siRNA-mediated knockdown of ASPP1 or ASPP2 leads to substantial RGC survival after axonal injury. Fourth, the neuroprotective effect of siASPP2 involves downregulation of the p53 apoptotic targets PUMA and Fas/ CD95, and siRNAs against PUMA or Fas/ CD95 effectively promote RGC survival. Our data support a novel, key role of proapoptotic ASPP family members in the regulation of retinal neuron death.

Axonal injury is a major cause of neuronal loss in the CNS of adult mammals and it is the primary damaging event in most optic neuropathies, including glaucoma. Using an axotomy model, we found that p53 phosphorylation and upregulation of the p53 proapoptotic targets PUMA and Fas/CD95 are markedly increased at $1 \mathrm{~d}$ after injury, a time that precedes the onset of RGC death. In adult rodents, RGCs survive for $5 \mathrm{~d}$ after axotomy and then die abruptly (VillegasPérez et al., 1993; Berkelaar et al., 1994); therefore, this finding suggests that early p53 activation plays a causal role in injury-induced RGC loss. In support of this, our data further demonstrate that p53 deficiency promotes RGC survival after axotomy in a gene dose-dependent manner. This is consistent with studies showing that inactivation of the p53 gene attenuates RGC death following ischemia, excitotoxicity, or optic nerve crush (Rosenbaum et al., 1998; Li et al., 2002; Park et al., 2008).

ASPP1 and ASPP2 are cofactors that enhance the proapoptotic function of p53, but not its ability to regulate cell cycle arrest (Samuels-Lev et al., 2001). ASPP proteins are known to interact directly with the p53 DNA-binding domain through their ankyrin and $\mathrm{SH} 3$ domains, readily increasing its transcriptional activity at proapoptotic gene promoters (Gorina and Pavletich, 1996; Patel et al., 2008). We demonstrate that RGCs express high endogenous levels of ASPP1 and ASPP2 that do not change after axotomy, supporting the hypothesis that these neurons become vulnerable to injuryinduced activation of p53. It is unlikely that the function of ASPP1 and ASPP2

changes after injury, but rather that they are poised to act as cofactors to facilitate rapid p53-mediated transcriptional activation of PUMA and Fas/CD95 following axotomy. This is consistent with previous studies showing that other p53 cofactors, such as Brn-3b and SP1, can effectively modulate p53 activity without undergoing stress-induced changes in function or expression levels (Budhram-Mahadeo et al., 2006; Dhar et al., 2006; Chatoo et al., 2011).

To address the functional role of ASPP1/2, we used a siRNAbased approach to knockdown ASPP1/2 gene expression in vivo.

E the mean \pm SEM
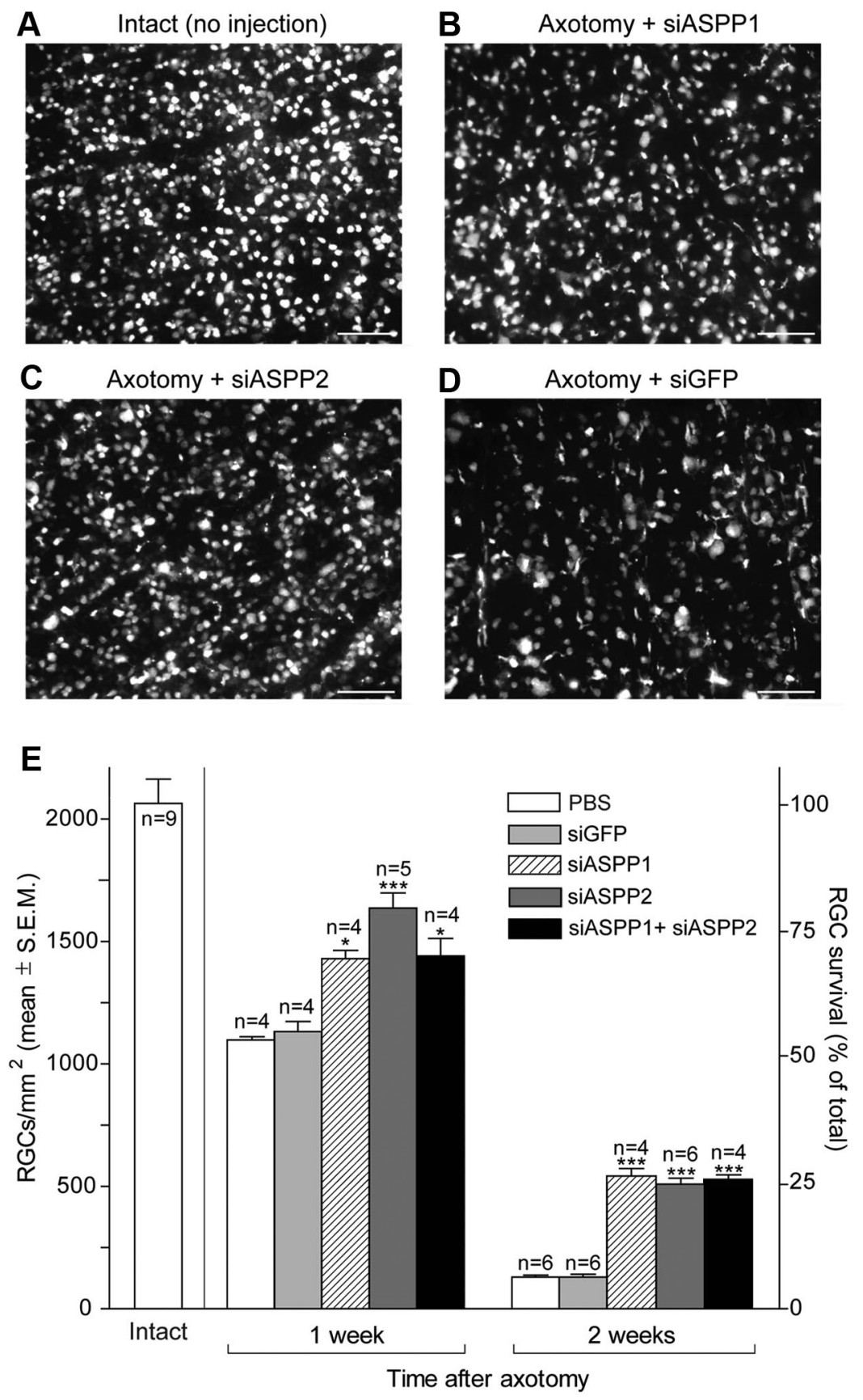

Figure 5. ASPP1 and ASPP2 knockdown protects RGCs from axotomy-induced death. Fluorogold-labeled RGCs in flat-mounted retinas from a representative noninjured eye $(\boldsymbol{A})$ or axotomized eyes treated with siASPP1 $(\boldsymbol{B}), \operatorname{siASPP} 2(\boldsymbol{C})$, or control siGFP $(\boldsymbol{D})$ at 1 week postinjury. Scale bars, $100 \mu \mathrm{m}$. E, Quantitative analysis of RGC survival following intraocular injection of siASPP1 (hatched), siASPP2 (dark gray), combined siASPP1 and siASPP2 (black), control siGFP (light gray) or PBS (white) (ANOVA, ${ }^{* * *} p<0.001 ;{ }^{*} p<$ 0.05). The density of RGCs in intact, uninjured Sprague Dawley rat retinas is shown as reference (open bar). Data are expressed as

siRNA has been successfully delivered to RGCs via injection into the optic nerve or the superior colliculus (Lingor et al., 2005; Koeberle et al., 2010), but the invasive nature of these approaches greatly limits their application. We chose to deliver siRNA molecules by intravitreal injections, which led to effective siRNA uptake by RGCs, as previously demonstrated by us (Ahmed et al., 2011). We cannot rule out that other retinal cells also incorporated siRNA injected into the vitreous chamber; however, we show that this strategy is suitable for silencing genes that are highly enriched in RGCs. Our results show that targeted siRNA 

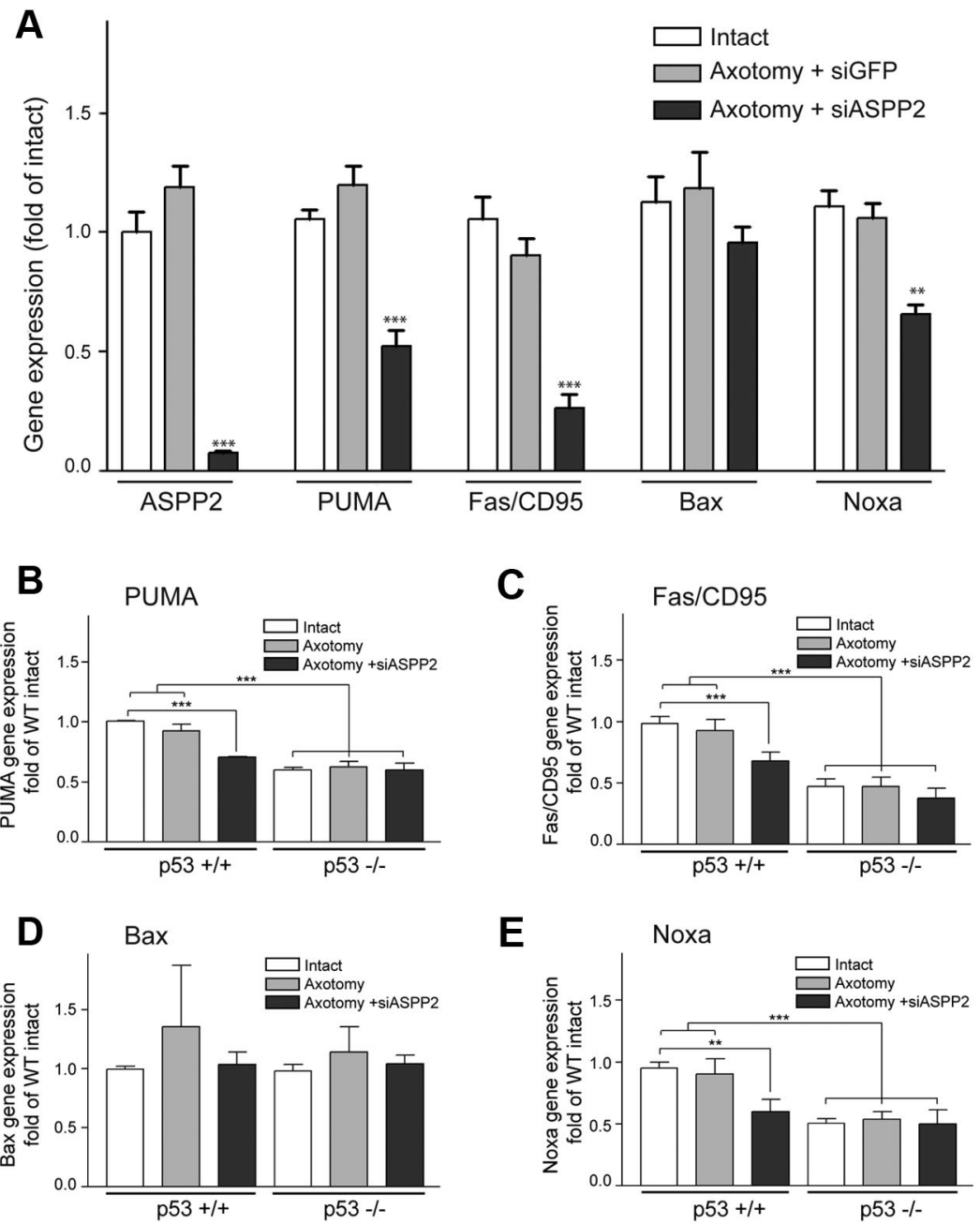

Figure 6. siASPP2-mediated knockdown of PUMA, Fas, and Noxa depends on $p 53$ transcriptional activity. $\boldsymbol{A}$, Real-time qPCR analysis of rat retinal samples at $6 \mathrm{~h}$ after axotomy and siASPP2 administration revealed that ASPP2 knockdown leads to downregulation of PUMA, Fas/CD95, and Noxa (ANOVA, ${ }^{* * *} p<0.001 ;{ }^{* *} p<0.01$ ), but not Bax (ANOVA, $\left.p>0.5\right)$ gene expression. $\boldsymbol{B}-\boldsymbol{E}, q P C R$ of retinal samples from $\mathrm{p} 53$-null mice and wild-type littermate controls collected at $6 \mathrm{~h}$ after axotomy and siASPP2 injection. Transcript levels of PUMA, Fas/CD95, and Noxa were significantly reduced in noninjured or axotomized p53-null mice with respect to wild-type littermates. Moreover, ASPP2 knockdown effectively reduced PUMA, Fas/CD95, and Noxa gene expression in axotomized retinas from $p 53$ wild-type mice, but not from $p 53$ knock-out mice $(\boldsymbol{B}, \boldsymbol{C}, \boldsymbol{E})$ (ANOVA, ${ }^{* * *} p<0.001$; ${ }^{* *} p<$ 0.01). Bax gene expression remained unchanged (D).

successfully downregulated retinal ASPP1 and ASPP2 by 85$90 \%$ at $24 \mathrm{~h}$ after intravitreal delivery, but this effect was transient since protein levels were restored by $48 \mathrm{~h}$. Despite this short-lived effect, our data demonstrate a strong neuroprotective effect of siASPP $1 / 2$, suggesting that there is a window of opportunity soon after axotomy in which ASPP1/2 knockdown counters the proapoptotic effect of $\mathrm{p} 53$. This is supported by our observation that the levels of phospho-p53, PUMA, and Fas/CD95, which are upregulated at $24 \mathrm{~h}$ after axotomy, drop to basal levels at $7 \mathrm{~d}$ postinjury. Therefore, siASPP1/2 treatment to knockdown proapoptotic p53 targets during this critical period effectively attenuates RGC loss.

To identify the mechanism by which ASPP1/2 silencing delayed RGC death, we examined mRNA and protein levels of p53 proapoptotic targets. Comparative gene expression analysis revealed a substantial downregulation of PUMA, Fas/CD95, and Noxa in axotomized rat retinas derived from eyes treated with siASPP2 but not with control siRNA. Importantly, ASPP2 knockdown effectively reduced PUMA, Fas/CD95, and Noxa expression in axotomized retinas from p53 wild-type but not from p53-null mice, demonstrating that downregulation of these apoptotic genes depends on p53 transcriptional activity. At the protein level, siASPP2 substantially reduced retinal PUMA and Fas/CD95 proteins, while Noxa remained unchanged. Consistent with this, our data show that while targeted siRNA against Noxa failed to promote significant neuroprotection, siRNAs against PUMA or Fas/CD95 knockdown led to robust RGC survival, indicating that these molecules play a functional role in axotomy-induced RGC death. PUMA is a $\mathrm{BH} 3$-only protein and a potent inducer of cell death, but so far there have been no reports of its role on RGC death. The proapoptotic activity of PUMA requires its interaction with anti-apoptotic Bcl-2 family members, localization to the mitochondria, and induction of cytochrome $c$ release leading to caspase activation and cell death (Nakano and Vousden, 2001). Biochemical studies suggest that PUMA regulates mitochondrial outer membrane permeabilization by binding to anti-apoptotic Bcl-2 proteins, which results in de-repression and activation of Bax or Bak (Chipuk and Green, 2009). Although we did not detect changes in Bax mRNA or protein levels in the presence of siASPP2, we cannot entirely rule out a decrease in Bax activity following PUMA downregulation. PUMA can release cytosolic p53 from its inactive complex with Bcl-XL to form a PUMABcl-XL complex, allowing p53 to activate Bax (Chipuk et al., 2005). Therefore, a decrease in PUMA levels could potentially reduce Bax activity by reducing its release from $\mathrm{Bcl}-\mathrm{XL}$.

Our data also demonstrate that ASPP2 knockdown leads to downregulation of Fas/CD95 and that siRNA-mediated Fas/ CD95 silencing was neuroprotective. Fas/CD95 is a death receptor of the tumor necrosis factor receptor superfamily of singlepass transmembrane proteins (Ashkenazi, 2002; Peter et al., 2007). Fas/CD95 is activated by Fas ligand (FasL) leading to the recruitment of the adaptor protein FADD (Fas-associated death domain) and activation of caspase 8 (Haase et al., 2008). Analysis of $\mathrm{p} 53$ responsive elements in the $\mathrm{CD} 95$ gene revealed a role for p53 in Fas/CD95 transcription (Schilling et al., 2009). Furthermore, nuclear ASPP1 can activate p53-induced Fas/CD95 expression (Aylon et al., 2010). FasL has been shown to increase in retinal microglia in a rat model of ocular hypertension (Ju et al., 2006) and FasL-positive autoreactive T cells have been implicated in the loss of RGCs following heat shock protein immunization (Wax et al., 2008). More recently, the membrane-bound form of FasL was implicated in glaucomatous RGC degeneration (Gregory et al., 2011). Collectively, these studies support a role for Fas/CD95 in RGC death. Our data, specifically, demonstrate 
that Fas/CD95 contributes to ASPP1/2p53 proapoptotic signaling and that Fas/ CD95 downregulation promotes marked RGC protection after axonal injury.

Recent studies have unveiled a novel and unexpected role for p53 in the promotion of neurite outgrowth and axonal regeneration that is independent of its proapoptotic function (Di Giovanni and Rathore, 2012). Indeed, p53 gene silencing or dominant-negative forms of p53 have been shown to inhibit neurotrophindependent outgrowth in vitro and axonal regeneration in vivo (Di Giovanni et al., 2006; Zhang et al., 2006; Tedeschi et al., 2009b). Of interest, p53 acetylation at specific lysine residues is thought to be required for the p53 growth-promoting effects (Tedeschi et al., 2009a; Gaub et al., 2010). More recently, viral-mediated overexpression of the histone acetyltransferase p300 in RGCs increased axonal regeneration within the injured optic nerve (Gaub et al., 2011). We have previously demonstrated that signaling pathways that lead to RGC survival may differ from those that promote RGC axon regeneration (Pernet and Di Polo, 2006). Therefore, although our current data demonstrate a proapoptotic role of p53, we cannot rule out the possibility that p53 might enhance RGC axon growth through activation of different signaling pathways. In this context, it should be of interest to assess the role of ASPP $1 / 2$ on axonal regeneration following optic nerve injury.

In conclusion, we used a loss-offunction approach to identify the role of the p53 activators ASPP1 and ASPP2 in retinal neuron death following optic nerve axotomy. Our data demonstrate a novel and prominent role of the proapoptotic ASPP1/2 proteins in the death of RGCs that involves the p53 targets PUMA and Fas/CD95. These findings expand our understanding of the molecular basis of RGC neurodegeneration and might have implications for the design of strategies for neuroprotection in the injured CNS.

\section{References}

Agirre X, Román-Gómez J, Jiménez-Velasco A, Garate L, Montiel-Duarte C, Navarro G, Vázquez I, Zalacain M, Calasanz MJ, Heiniger A, Torres A, Minna JD, Prósper F (2006) ASPP1, a common activator of TP53, is inactivated by aberrant methylation of its promoter in acute lymphoblastic leukemia. Oncogene 25:1862-1870. CrossRef Medline

Ahmed Z, Kalinski H, Berry M, Almasieh M, Ashush H, Slager N, Brafman A, Spivak I, Neeha Prasad N, Mett I, Shalom E, Alpert E, Di Polo A, Feinstein E, Logan A (2011) Ocular neuroprotection by siRNA targeting caspase-2. Cell Death Dis 2:e173. CrossRef Medline

Aikawa T, Shinzawa K, Tanaka N, Tsujimoto Y (2010) Noxa is necessary for hydrogen peroxide-induced caspase-dependent cell death. FEBS Letts 584:681-688. CrossRef Medline

Amano T, Nakamizo A, Mishra SK, Gumin J, Shinojima N, Sawaya R, Lang FF (2009) Simultaneous phosphorylation of p53 at serine 15 and 20 induces SEM.
B
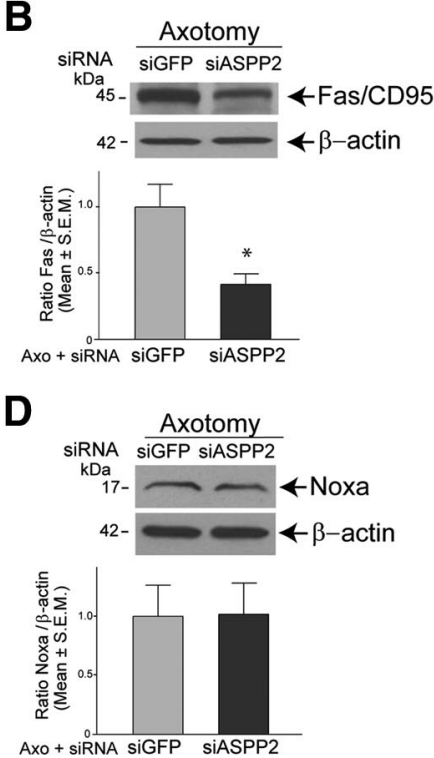

H

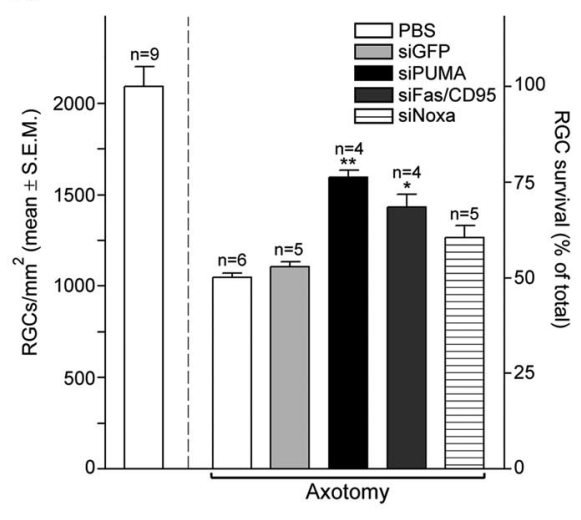

Figure 7. siASPP2 protects RGCs through downregulation of the 553 proapoptotic targets PUMA and Fas/CD95. Western blot analysis of axotomized and injected retinal samples at $24 \mathrm{~h}$ after siRNA administration show that PUMA and Fas/CD95 protein levels

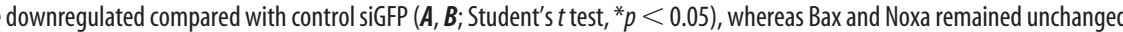
Din and siNoxa downregulated endogenous retinal Fas/CD95 (E), PUMA $(\boldsymbol{F})$, and Noxa $(\boldsymbol{G})$ protein levels, respectively, com-

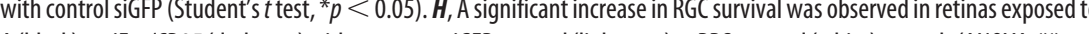
$0.01 ;{ }^{*} p<0.05$ ). Administration of siNoxa (horizontal lines) did not result in significant RGC survival (ANOVA, $p>0.05$ ). The density of RGCs in intact, uninjured Sprague Dawley rat retinas is shown as reference (open bar). Data are expressed as the mean \pm

apoptosis in human glioma cells by increasing expression of proapoptotic genes. J Neurooncol 92:357-371. CrossRef Medline

Ao Y, Rohde LH, Naumovski L (2001) p53-interacting protein 53BP2 inhibits clonogenic survival and sensitizes cells to doxorubicin but not paclitaxel-induced apoptosis. Oncogene 20:2720-2725. CrossRef Medline

Armstrong JL, Flockhart R, Veal GJ, Lovat PE, Redfern CP (2010) Regulation of endoplasmic reticulum stress-induced cell death by ATF4 in neuroectodermal tumor cells. J Biol Chem 285:6091-6100. CrossRef Medline

Ashkenazi A (2002) Targeting death and decoy receptors of the tumournecrosis factor superfamily. Nat Rev Cancer 2:420-430. CrossRef Medline

Aylon Y, Ofir-Rosenfeld Y, Yabuta N, Lapi E, Nojima H, Lu X, Oren M (2010) The Lats2 tumor suppressor augments p53-mediated apoptosis by promoting the nuclear proapoptotic function of ASPP1. Gene Dev 24:2420-2429. CrossRef Medline

Bergamaschi D, Samuels Y, O’Neil NJ, Trigiante G, Crook T, Hsieh JK, O'Connor DJ, Zhong S, Campargue I, Tomlinson ML, Kuwabara PE, Lu 
$\mathrm{X}$ (2003) iASPP oncoprotein is a key inhibitor of p53 conserved from worm to human. Nat Genet 33:162-167. CrossRef Medline

Bergamaschi D, Samuels Y, Sullivan A, Zvelebil M, Breyssens H, Bisso A, Del Sal G, Syed N, Smith P, Gasco M, Crook T, Lu X (2006) iASPP preferentially binds p53 proline-rich region and modulates apoptotic function of codon 72-polymorphic p53. Nat Genet 38:1133-1141. CrossRef Medline

Berkelaar M, Clarke DB, Wang YC, Bray GM, Aguayo AJ (1994) Axotomy results in delayed death and apoptosis of retinal ganglion cells in adult rats. J Neurosci 14:4368-4374. Medline

Boehme KA, Blattner C (2009) Regulation of p53-insights into a complex process. Crit Rev Biochem Mol Biol 44:367-392. CrossRef Medline

Budhram-Mahadeo VS, Bowen S, Lee S, Perez-Sanchez C, Ensor E, Morris PJ, Latchman DS (2006) Brn-3b enhances the pro-apoptotic effects of p53 but not its induction of cell cycle arrest by cooperating in trans-activation of bax expression. Nucl Acids Res 34:6640-6652. CrossRef Medline

Chang JR, Ghafouri M, Mukerjee R, Bagashev A, Chabrashvili T, Sawaya BE (2012) Role of p53 in neurodegenerative diseases. Neurodegener Dis 9:68-80. CrossRef Medline

Chatoo W, Abdouh M, David J, Champagne MP, Ferreira J, Rodier F, Bernier G (2009) The polycomb group gene Bmil regulates antioxidant defenses in neurons by repressing p53 pro-oxidant activity. J Neurosci 29: 529-542. CrossRef Medline

Chatoo W, Abdouh M, Bernier G (2011) p53 pro-oxidant activity in the central nervous system: implication in aging and neurodegenerative diseases. Antioxid Redox Signal 15:1729-1737. CrossRef Medline

Cheng L, Sapieha P, Kittlerová P, Hauswirth WW, Di Polo A (2002) TrkB gene transfer protects retinal ganglion cells from axotomy-induced death in vivo. J Neurosci 22:3977-3986. Medline

Chipuk JE, Green DR (2009) PUMA cooperates with direct activator proteins to promote mitochondrial outer membrane permeabilization and apoptosis. Cell Cycle 8:2692-2696. CrossRef Medline

Chipuk JE, Bouchier-Hayes L, Kuwana T, Newmeyer DD, Green DR (2005) PUMA couples the nuclear and cytoplasmic proapoptotic function of p53. Science 309:1732-1735. CrossRef Medline

Culmsee C, Mattson MP (2005) p53 in neuronal apoptosis. Biochem Biophys Res Comm 331:761-777. CrossRef Medline

Czauderna F, Fechtner M, Dames S, Aygün H, Klippel A, Pronk GJ, Giese K, Kaufmann J (2003) Structural variations and stabilising modifications of synthetic siRNAs in mammalian cells. Nucleic Acids Res 31:2705-2716. CrossRef Medline

Dhar SK, Xu Y, Chen Y, St Clair DK (2006) Specificity protein 1-dependent p53-mediated suppression of human manganese superoxide dismutase gene expression. J Biol Chem 281:21698-21709. CrossRef Medline

Di Giovanni S, Rathore K (2012) p53-dependent pathways in neurite outgrowth and axonal regeneration. Cell Tissue Res 349:87-95. CrossRef Medline

Di Giovanni S, Knights CD, Rao M, Yakovlev A, Beers J, Catania J, Avantaggiati ML, Faden AI (2006) The tumor suppressor protein p53 is required for neurite outgrowth and axon regeneration. EMBO J 25:4084-4096. CrossRef Medline

Dumaz N, Meek DW (1999) Serine15 phosphorylation stimulates p53 transactivation but does not directly influence interaction with HDM2. EMBO J 18:7002-7010. CrossRef Medline

Gaub P, Tedeschi A, Puttagunta R, Nguyen T, Schmandke A, Di Giovanni S (2010) HDAC inhibition promotes neuronal outgrowth and counteracts growth cone collapse through CBP/p300 and P/CAF-dependent p53 acetylation. Cell Death Differ 17:1392-1408. CrossRef Medline

Gaub P, Joshi Y, Wuttke A, Naumann U, Schnichels S, Heiduschka P, Di Giovanni S (2011) The histone acetyltransferase p300 promotes intrinsic axonal regeneration. Brain 134:2134-2148. CrossRef Medline

Gorina S, Pavletich NP (1996) Structure of the p53 tumor suppressor bound to the ankyrin and SH3 domains of 53BP2. Science 274:1001-1005. CrossRef Medline

Gregory MS, Hackett CG, Abernathy EF, Lee KS, Saff RR, Hohlbaum AM, Moody KS, Hobson MW, Jones A, Kolovou P, Karray S, Giani A, John SW, Chen DF, Marshak-Rothstein A, Ksander BR (2011) Opposing roles for membrane bound and soluble Fas ligand in glaucoma-associated retinal ganglion cell death. PLoS One 6:e17659. CrossRef Medline

Haase G, Pettmann B, Raoul C, Henderson CE (2008) Signaling by death receptors in the nervous system. Curr Opin Neurobiol 18:284-291. CrossRef Medline
Hamar P, Song E, Kökény G, Chen A, Ouyang N, Lieberman J (2004) Small interfering RNA targeting Fas protects mice against renal ischemiareperfusion injury. Proc Natl Acad Sci U S A 101:14883-14888. CrossRef Medline

Iwabuchi K, Bartel PL, Li B, Marraccino R, Fields S (1994) Two cellular proteins that bind to wild-type but not mutant p53. Proc Natl Acad Sci U S A 91:6098-6102. CrossRef Medline

Ju KR, Kim HS, Kim JH, Lee NY, Park CK (2006) Retinal glial cell responses and Fas/FasL activation in rats with chronic ocular hypertension. Brain Res 1122:209-221. CrossRef Medline

Koeberle PD, Wang Y, Schlichter LC (2010) Kv1.1 and Kv1.3 channels contribute to the degeneration of retinal ganglion cells after optic nerve transection in vivo. Cell Death Differ 17:134-144. CrossRef Medline

Lebrun-Julien F, Morquette B, Douillette A, Saragovi HU, Di Polo A (2009) Inhibition of p75NTR in glia potentiates TrkA-mediated survival of injured retinal ganglion cells. Mol Cell Neurosci 40:410-420. CrossRef Medline

Leon S, Yin Y, Nguyen J, Irwin N, Benowitz LI (2000) Lens injury stimulates axon regeneration in the mature rat optic nerve. J Neurosci 20:4615-4626. Medline

Li Y, Schlamp CL, Poulsen GL, Jackson MW, Griep AE, Nickells RW (2002) p53 regulates apoptotic retinal ganglion cell death induced by N-methylD-aspartate. Mol Vis 8:341-350. Medline

Lingor P, Koeberle P, Kügler S, Bähr M (2005) Down-regulation of apoptosis mediators by RNAi inhibits axotomy-induced retinal ganglion cell death in vivo. Brain 128:550-558. CrossRef Medline

Liu ZJ, Zhang Y, Zhang XB, Yang X (2004) Abnormal mRNA expression of ASPP members in leukemia cell lines. Leukemia 18:880. CrossRef Medline

Liu ZJ, Lu X, Zhang Y, Zhong S, Gu SZ, Zhang XB, Yang X, Xin HM (2005) Downregulated mRNA expression of ASPP and the hypermethylation of the $5^{\prime}$-untranslated region in cancer cell lines retaining wild-type p53. FEBS Lett 579:1587-1590. CrossRef Medline

Lopez CD, Ao Y, Rohde LH, Perez TD, O’Connor DJ, Lu X, Ford JM, Naumovski L (2000) Proapoptotic p53-interacting protein 53BP2 is induced by UV irradiation but suppressed by p53. Mol Cell Biol 20:8018-8025 . CrossRef Medline

Lossos IS, Natkunam Y, Levy R, Lopez CD (2002) Apoptosis stimulating protein of p53 (ASPP2) expression differs in diffuse large B-cell and follicular center lymphoma: correlation with clinical outcome. Leuk Lymphoma 43:2309-2317. CrossRef Medline

Mansour-Robaey S, Clarke DB, Wang YC, Bray GM, Aguayo AJ (1994) Effects of ocular injury and administration of brain-derived neurotrophic factor on survival and regrowth of axotomized retinal ganglion cells. Proc Natl Acad Sci U S A 91:1632-1636. CrossRef Medline

Nagase T, Ishikawa K, Suyama M, Kikuno R, Hirosawa M, Miyajima N, Tanaka A, Kotani H, Nomura N, Ohara O (1998) Prediction of the coding sequences of unidentified humangGenes. XII. The complete sequences of 100 new cDNA clones from brain which code for large proteins in vitro. DNA Res 5:355-364. CrossRef Medline

Nakano K, Vousden KH (2001) PUMA, a novel proapoptotic gene, is induced by p53. Mol Cell 7:683-694. CrossRef Medline

O'Connor JC, Wallace DM, O'Brien CJ, Cotter TG (2008) A novel antioxidant function for the tumor-suppressor gene p53 in the retinal ganglion cell. Invest Ophthalmol Vis Sci 49:4237-4244. CrossRef Medline

Park KK, Liu K, Hu Y, Smith PD, Wang C, Cai B, Xu B, Connolly L, Kramvis I, Sahin M, He Z (2008) Promoting axon regeneration in the adult CNS by modulation of the PTEN/mTOR pathway. Science 322:963-966. CrossRef Medline

Patel S, George R, Autore F, Fraternali F, Ladbury JE, Nikolova PV (2008) Molecular interactions of ASPP1 and ASPP2 with the p53 protein family and the apoptotic promoters PUMA and Bax. Nucleic Acids Res 36:5139-5151. CrossRef Medline

Pernet V, Di Polo A (2006) Synergistic action of brain-derived neurotrophic factor and lens injury promotes retinal ganglion cell survival, but leads to optic nerve dystrophy in vivo. Brain 129:1014-1026. CrossRef Medline

Pernet V, Hauswirth WW, Di Polo A (2005) Extracellular signal-regulated kinase $1 / 2$ mediates survival, but not axon regeneration, of adult injured central nervous system neurons in vivo. J Neurochem 93:72-83. CrossRef Medline

Perry VH (1981) Evidence for an amacrine cell system in the ganglion cell layer of the rat retina. Neuroscience 6:931-944. CrossRef Medline 
Peter ME, Budd RC, Desbarats J, Hedrick SM, Hueber AO, Newell MK, Owen LB, Pope RM, Tschopp J, Wajant H, Wallach D, Wiltrout RH, Zörnig M, Lynch DH (2007) The CD95 receptor: apoptosis revisited. Cell 129:447450. CrossRef Medline

Rosenbaum DM, Rosenbaum PS, Gupta H, Singh M, Aggarwal A, Hall DH, Roth S, Kessler JA (1998) The role of the p53 protein in the selective vulnerability of the inner retina to transient ischemia. Invest Ophthalmol Vis Sci 39:2132-2139. Medline

Samuels-Lev Y, O'Connor DJ, Bergamaschi D, Trigiante G, Hsieh JK, Zhong S, Campargue I, Naumovski L, Crook T, Lu X (2001) ASPP proteins specifically stimulate the apoptotic function of p53. Mol Cell 8:781-794. CrossRef Medline

Schilling T, Schleithoff ES, Kairat A, Melino G, Stremmel W, Oren M, Krammer PH, Müller M (2009) Active transcription of the human FAS/ CD95/TNFRSF6 gene involves the p53 family. Biochem Biophys Res Commun 387:399-404. CrossRef Medline

Slee EA, O'Connor DJ, Lu X (2004) To die or not to die: how does p53 decide? Oncogene 23:2809-2818. CrossRef Medline

Soussi T (2000) The $\mathrm{p} 53$ tumor suppressor gene: from molecular biology to clinical investigation. Ann N Y Acad Sci 910:121-137. CrossRef Medline

Tedeschi A, Nguyen T, Puttagunta R, Gaub P, Di Giovanni S (2009a) A p53-CBP/p300 transcription module is required for GAP-43 expression, axon outgrowth, and regeneration. Cell Death Differ 16:543-554. CrossRef Medline

Tedeschi A, Nguyen T, Steele SU, Feil S, Naumann U, Feil R, Di Giovanni S (2009b) The tumor suppressor p53 transcriptionally regulates cGKI ex- pression during neuronal maturation and is required for cGMPdependent growth cone collapse. J Neurosci 29:15155-15160. CrossRef Medline

Unger T, Sionov RV, Moallem E, Yee CL, Howley PM, Oren M, Haupt Y (1999) Mutations in serines 15 and 20 of human p53 impair its apoptotic activity. Oncogene 18:3205-3212. CrossRef Medline

Villegas-Pérez MP, Vidal-Sanz M, Rasminsky M, Bray GM, Aguayo AJ (1993) Rapid and protracted phases of retinal ganglion cell loss follow axotomy in the optic nerve of adult rats. J Neurobiol 24:23-36. CrossRef Medline

Vives V, Su J, Zhong S, Ratnayaka I, Slee E, Goldin R, Lu X (2006) ASPP2 is a haploinsufficient tumor suppressor that cooperates with p53 to suppress tumor growth. Genes Dev 20:1262-1267. CrossRef Medline

Wade M, Wang YV, Wahl GM (2010) The p53 orchestra: Mdm2 and Mdmx set the tone. Trends Cell Biol 20:299-309. CrossRef Medline

Wax MB, Tezel G, Yang J, Peng G, Patil RV, Agarwal N, Sappington RM, Calkins DJ (2008) Induced autoimmunity to heat shock proteins elicits glaucomatous loss of retinal ganglion cell neurons via activated T-cellderived Fas-ligand. J Neurosci 28:12085-12096. CrossRef Medline

Yang JP, Hori M, Sanda T, Okamoto T (1999) Identification of a novel inhibitor of nuclear factor-kappaB, RelA-associated inhibitor. J Biol Chem 274:15662-15670. CrossRef Medline

Zhang J, Yan W, Chen X (2006) p53 is required for nerve growth factormediated differentiation of PC12 cells via regulation of TrkA levels. Cell Death Differ 13:2118-2128. CrossRef Medline 